\title{
HOMAGE TO CATALONIA REVISITED: FROM VULNERABILITY TO RESISTANCE
}

\author{
Yolanda Caballero Aceituno*
}

\begin{abstract}
This paper focuses on an analysis of Homage to Catalonia (1938), with a view to highlighting the necessity of revisiting the texts from the past, in order to establish a deep and mutually enriching dialogue between discourses and ideologies belonging to different periods. The texts from the past should not be considered as frozen fossils, but rather, as words alive throughout time, subject to a continuous process of re-interpretation in the present. I intend to show how, in Homage to Catalonia, George Orwell inserts a peculiar philosophy of resistance against the timeless problem of alienation which, due to its contemporary relevance, goes beyond the contextualisation of the novel in the Spanish Civil War.

Keywords: Literature of political commitment, the Spanish Civil War, The texts from the past and their timeless values, Alienation and vulnerability versus revolution and resistance

Resumen: El presente artículo se centra en analizar Homage to Catalonia (1938) con vistas a subrayar la necesidad de una vuelta continua hacia los textos del pasado para establecer un diálogo profundo y enriquecedor entre los discursos y las ideologías de épocas distintas. Los textos del pasado no deben ser considerados como fósiles congelados, sino como palabra viva en el tiempo, sujeta a un constante proceso de reinterpretación desde el presente. Pretendo subrayar cómo en Homage to Catalonia George Orwell inserta una filosofía de resistencia contra el problema atemporal de la alineación que transciende, por su significación para la época actual, la contextualización de la novela en la Guerra Civil Española.

Palabras clave: Literatura de compromiso político, Guerra Civil Española, los textos del pasado y sus valores atemporales, alienación y vulnerabilidad versus revolución y resistencia.
\end{abstract}

\begin{abstract}
To-morrow for the young the poets exploding like bombs, The walks by the lake, the weeks of perfect communion; To-morrow the bicycle races

Through the suburbs on summer evenings. But to-day the Struggle
\end{abstract}

(W. H. Auden, Spain)

\footnotetext{
Fecha de recepción: abril 2004

Fecha de aceptación y versión final: julio 2004

** Profesora del Departamento de Filología Inglesa, Universidad de Jaén; $₫$ ycaballero@ujaen.es.
} 
The aim of this paper is to analyse the humanistic contributions of Homage to Catalonia $^{1}$. From my point of view, literary works acquire a humanistic significance when readers come to conceive their teleology as meaningful and useful for their own lives, when they perceive that their message goes beyond fictional boundaries. Homage to Catalonia seems designed to encourage these reactions. Therefore, I am not concerned with analysing the literary qualities of Orwell's creation. Nor do I purport to revisit its political ideals. Rather, I want to highlight how the novel recreates the transformation of ideological vulnerability into an attitude of resistance, a process which makes the novel relevant to contemporary readers. In my opinion, Orwell's Homage dramatises universal emotions and reflects on timeless problems.

In the Homage, Orwell's vulnerability emerges as a painful psychological experience: he had realised that totalising discourses — namely represented by fascism- were powerful enough to threaten his freedom. This vulnerability can be described as ideological because the most important trait of Orwell's personality is his blind belief in the ideals which fascism wanted to exterminate. Fascism was a serious threat, and those who were supposed to defeat its aspirations soon lost their revolutionary ardour. As a free-thinker, Orwell continued to believe that a better life was possible. However, the many hardships that he experienced in Spain temporarily suppressed his inner desires and left his most sacred dreams suspended between a hopeless present and an unattainable future.

Perhaps, as Alldritt has pointed out, the feuds, the coalitions and the interrelationships of the various political parties - confusingly referred to throughout the novel only by their initials - are immensely complex, and of real interest only to the historians of the Spanish Civil War (1969: 85). Nevertheless, George Orwell made a discovery which, in my opinion, goes far beyond the historical scope of the 1930's: he illuminated the possibility of rewriting his weakness into ideological resistance ${ }^{2}$, into a persistent will to change the world. Orwell wrote Homage to Catalonia to purify his faith in a more equitable social order and, above all, his faith in freedom. The whole experience left him "with no less but more belief in the decency of human beings" (186).

In the 1960's Thomas stated that there were about 3,000 books or pamphlets about the Spanish Civil War, and that nearly all were repetitious or ephemeral. He also declared that "about half a dozen of these books are worth reading carefully for their own sake even

\footnotetext{
${ }^{1}$ Let me clarify the notion of 'humanism' which underlies the phrase 'humanistic significance.' I agree with Faulkner's definition: humanism is an ethos which places human happiness as its central concern. Its spirit is flexible and non-dogmatic, since it refuses to sacrifice human happiness to any rigid orthodoxy. Humanism expects no finalities, but does ascribe value to human achievements of all kinds, from art and politics to friendship and love (1975: 1-7). In the light of this definition, the humanistic significance of Homage to Catalonia lies in Orwell's achievement: throughout the pages of his novel, he rewrites ideological vulnerability into ideological resistance and dramatises a revolution against alienating dogmas.

${ }^{2}$ I have selected the term 'rewriting' because it highlights that Orwell's discovery is enacted through the act of writing. By immortalising his emotions, he is able to share his humanistic discovery with contemporary readers. 'Rewriting' also evokes a powerful image in which the teleology of the Homage is metaphorically contained: Orwell writing revolutionary slogans on the walls, slogans which had been previously banned and removed from every street in Barcelona.
} 
$n o w^{3}$, and the best of these is Homage to Catalonia" (1964: 150). Orwell's novel is not concerned with political propaganda, with the restriction of its validity to the historical scope of the Spanish Civil War. As Mairet has pointed out, an outstanding feature of the Homage is "its freedom from political obscurantism" (1997: 127), because its message goes beyond the idealisation of the POUM (Working Party of Marxist Unification) and beyond the description of the "political controversy and the mob of parties and subparties" (216) ${ }^{4}$. The novel was not merely designed to touch the hearts of committed or uncommitted Socialists, of those concrete historical entities who experienced the optimism of 1936 and the defeat of 1939. As Pierce and de Voogd have noted, the contemporary is someone or something, not just existing at the same time, but at an equivalent historical moment (1996: 3). The value of the Homage nowadays lies in the fact that the writer's homage is an homage to the human potential to overcome the timeless problem of alienation. The word 'homage' contains Orwell's vulnerability rewritten as "faith in mankind, in the human ability to struggle, to salvage civilization" (Gottlieb, 1992: 220).

Through the pages of Homage to Catalonia, Orwell constructs his personal identity as something lyrical, as something deviating from prosaic routine and from conformist patterns of behaviour. He was an active participant in the Spanish conflict during the months in which Spain became a myth. The Spanish Civil War broke out in a vulnerable world where freedom was threatened by the fascist powers embodied by Italy and Germany. In 1936, Mussolini had declared his intention of establishing a New Roman Empire. Cunningham noted that liberal people all over the world welcomed the Spanish conflict with "a mixture of fear and wish and the prevailing sense of apocalypse at last really come", and due to this mixture of heightened, but conflicting emotions, as well as to the consideration of Spain as a decisive locus for securing a better future, "the Spanish Civil War has passed into myth and furnished a hardy set of myths" (1996: 30). Volunteers coming to fight for the Republic dreamed that they sang the Internationale to Adolf Hitler and, indeed, "many of those on the Left who didn't volunteer to serve in Spain, anguished about it for years afterwards" (Nelson and Hendricks, 1996: 30), since they lost the opportunity of becoming active participants in the construction of the temporary Spanish revolution ${ }^{5}$. Orwell's literary style in Homage to Catalonia, based on authenticity, on "his naturalistic talent for the evocation of empirical detail" (Freedman, 1988: 106), lacked the literary genius to capture his feelings as lyrically as Hemingway did, for instance, in the following passage of For Whom the Bell Tolls:

You felt you were taking part in a crusade. [...]. You felt, in spite of all bureaucracy and inefficiency and party strife something that was like the feeling you expected to have and did

\footnotetext{
${ }^{3}$ Emphasis added. The 'now' uttered in the 1960's could be equally applied to the historical scope of 2005, which is the spirit of this discussion.

4 'Political controversy' refers, namely, to the conflicts between Anarchists and Communists, which shall be described later on.

${ }^{5}$ Nelson and Hendricks entitle the introduction to their book "I dreamed I sang the Internationale to Adolf Hitler". This title alludes to a dream that recurs throughout all the letters written by American volunteers: the dream of a more equitable social order, a dream that in the Great Depression of the 1930's seemed not only possible, but necessary (1996: 14).
} 
not have when you made your first communion. It was a feeling of consecration to a duty toward all the oppressed of the world which would be as difficult and embarrassing to speak about as religious experience and yet it was authentic as the feeling you had when you heard Bach, or stood in Chartres Cathedral or the Cathedral at León and saw the light coming through the great windows. (1999: 251)

Yet, what is lyricism? Can we describe the Homage as lyrical? According to Zimmerman, "defining lyricism has always been an inexact science, since the mode's uses vary tremendously between and, within, different periods and cultures" (1999: 3). Dunn provides a definition based on the idea that lyricism not only deals with the sublime expression of intimate emotions:

Lyricism is drawn from an ability to engage with the materials of ordinary life, and them absorb them, not necessarily to transcend them, or adjust ordinariness to the mysterious or the irrational; instead, although very different from each other in convictions, backgrounds and styles, and in nationality, they prove that poetry begins in reality as well as in the imagination that apprehends it (1988: 2).

According to Dunn's 'democratised' conception of lyricism, Orwell's novel can be considered as a lyrical homage, dedicated to those simple people who were responsible for the construction of Barcelona as a temporary myth. The Homage is written for those who, in difficult times, fought for the preservation of that revolutionary social order which they had previously created. A text can be defined as lyrical when it enhances human greatness under distressing historical conditions. From my point of view, lyricism is produced in the revolts against routine, against dehumanising codes and alienating principles. It is based on the belief that unexplored, ideal worlds are still available for us. In this sense, Homage to Catalonia fulfils every requirement to be considered as a truly lyrical book. "The international prestige of fascism [...] had been hunting me like a nightmare", Orwell wrote (134). To exorcise his fears, he writes a book in which he dramatises his vulnerability in Spain not as a negative experience, but as the necessary and glorious consequence of being 'ideologically alive' and committed to the dream of a better world in the most hostile of environments. The resolution of the conflict between the weakness of a POUM militiaman, and the strength of a true socialist ${ }^{6}$, transformed Homage to Catalonia into a

\footnotetext{
${ }^{6}$ In my opinion, this duality (weakness and strength) is the most powerful descriptor of Orwell's situation in Spain. Although Orwell's experiences in Spain purified his belief in Socialism, he was also a member of the POUM, a vulnerable political party. If, at the beginning of the conflict, the unity of Socialists, Anarchists and Communists against fascism was unquestionable, the frictions between the Anarchists and the Communist government were soon evident. The CNT, FAI and POUM forces held the working-class suburbs in Barcelona, whereas the armed police-forces and the PSUC (Communists and Socialists), held the central and official portion of the town. On 3 May, the Government decided to take over the Telephone Exchange Building, which had been operated since the beginning of the war mainly by Anarchist workers. As Orwell noted, "it was alleged that it was badly run and that official calls were being tapped" (217). However, "it was made the excuse for bringing Catalonia under the direct control of Valencia, for hastening the break-up of the militias and for the suppression of the POUM" (218). As a sign of protest, the next morning, barricades were built all over the town and there was no break in the fighting until the morning of 6 May: "the official leaders of the CNT had joined with those of the UGT in imploring everyone to go back to work; above all, food was running short. In such circumstances,
} 
real homage to our possibilities to face alienation. Contemporary readers may interpret the Spanish Civil War, if not as a pretext, certainly as the mere background of Orwell's humanistic discovery.

George Orwell "had come to Spain with some notion of writing newspaper articles, but [he] had joined the militia almost immediately because at that time [...] it seemed the only conceivable thing to do" (2). When he arrived in Barcelona, in late December 1936, he felt that he was in the midst of an atmosphere where "above all, there was a belief in the revolution and the future, a feeling of having suddenly emerged into an era of equality and freedom" (4). He thought that it was worth risking his life to preserve the purity of the Catalonian micro-cosmos. However, the beginning of September that year had brought defeat to the Spanish government on all fronts. The invincible spirit of the no pasarán was being progressively stifled ${ }^{7}$. As Thomas has pointed out, "bravery and emotion could win street battles, but were naturally inadequate against the legionaries and the regulares" (1964: 265). In September, Largo Caballero formed a government. The Communists joined with him and acquired great power: they believed that the main tasks of the proletarian revolution were already fulfilled, and that the Civil War simply demanded unity against Fascism. The Anarchists refused to join a government which they considered dangerously close to bourgeois democracy. In fact, Largo Caballero's government started to paralyse the process of revolution: the political committees which had sprung up in all pueblos in July were being replaced by municipal councils. An effort was also made to end the collective management of factories, seeking to bring such concerns under State control, for instance, by making credit difficult for Anarchist factories (Thomas, 1964: 366). Alldritt notes the extreme fragility of the revolution at this point: "not only was the surge of

nobody was sure enough of the issue to go on fighting. By the afternoon of 7 May conditions were almost normal. That evening six thousand Assault Guards, sent by sea from Valencia, arrived and took control of the town" (218). The spirit of the revolution seemed to have been crushed: "the only people who even talked in a revolutionary strain were the Friends of Durruti, a small extremist group within the FAI, and the POUM" (219). The CNT leaders soon dismissed their responsibility concerning the people's rising. However, "the POUM leaders did not disown the affair, in fact they encouraged their followers to remain at the barricades" (220). The insurrection soon appeared as engineered solely by the POUM, which soon was described as an association of Trotskyists who were stabbing the Spanish Government in the back. Consequently, the POUM was outlawed. "Any internal disorder was likely to aid Franco" (226), Orwell acknowledged. This statement contains Orwell's weakness: his ideological disillusionment.

7 The words ¡No pasarán! were uttered in Madrid by Dolores Ibárruri, "La Pasionaria," on the same night of the fascist rising. She seemed to imply that the rebels would never conquer Madrid. The people of the city had organised into untrained militias who fought bravely to defend the passes through the Guadarrama mountains to the city's north. However, the Nationalists began to organise an attack on Madrid from the South-West. As the rebel columns approached Madrid, there was widespread expectation that the city would fall. However, on November 7, Madrid's defenders found a highly detailed plan for the conquest of the city in the corpse of a fascist officer. The plan was very specific and enabled the city to position its best forces in strategic places. The following day, the first International Brigades marched through the city, signalling world support for the city's defenders. Madrid acquired a mythical status. It came to be considered as 'the heart of the world'. General Varela proclaimed: "Here in Madrid is the universal frontier that separates liberty and slavery. It is here in Madrid that two incompatible civilisations undertake their great struggle: love against hate, peace against war, the fraternity of Christ against the tyranny of the Church [...] This is Madrid. It is fighting for Spain, for humanity, for justice, and with the mantle of its blood, it shelters all human beings! Madrid! Madrid!" (qtd. in Nelson and Hendricks, 1996: 5). 
feeling which created the rising unmantainable over a long period of time, but also the forces of self-interest and political expediency were always ready to exploit, pervert, vilify or destroy it" (1969: 91). In For Whom The Bell Tolls Agustín, a young guerrillero, confesses his inner fears to Robert Jordan: " "They say that the government moves further to the right each day. That in the republic no longer say Comrade but Señor and Señora. [...] Are we to win this war and lose the revolution?"' (1999: 304). In the Homage, Orwell internalised the extreme fragility of the revolution as his own fragility because "he was really what hundreds of others only pretended to be: really classless, really a socialist, really truthful" (Spender, 1997: 134).

Orwell had time, though, to experience the construction of Barcelona as a true worker's state, where even the bootblacks, with their boxes painted red and black, had been collectivised:

On a ruinous wall I came upon a poster dating from the previous year and announcing that 'six handsome bulls' would be killed in the arena on such and such a date. How forlorn its faded colours looked! Where were the handsome bulls and the handsome bullfighters now? It appeared that even in Barcelona there were hardly any bullfights nowadays; for some reason, all the best matadors were Fascists (14).

However, immediately after describing his first impressions about revolutionary Barcelona, he inserts in the Homage a prophetic, pessimistic sentence: "I didn't realise that great numbers of well-to-do bourgeois were simply lying low and disguising themselves as proletarians for the time being" (3). In fact, the mind-style of the Homage is marked by a pervasive foreshadowing of defeat. As Reilly has pointed out, Orwell, so sensitive to bad smells, was "on olfactory alert" (1986: 38). As someone extremely committed and oversensitised, he perceived the rottenness of the Republic in the small intra-historic details which were undermining the process of revolution, converting them, after a literary treatment, into lyrical and powerful symbols of decadence. He witnessed how militiamen laughed at the women who had fought bravely in the street battles of July, and regretted that baskets full of bread were thrown away at every meal in the Lenin barracks, while the civilian population were short of food (5-6). Although these fatalist signs constantly tell him that a war for democracy is "a racket the same as any other" (132), he rebels against this idea, and this position made him extremely vulnerable to despair.

From a thematic point of view, the dramatisation of vulnerability is one of the most prominent features of Orwell's narrative. In fact, the book itself was vulnerable to those determined to distort it because, as Gorer has pointed out, it was going to be abused not only by Conservatives, but also by Communists (1997: 123). According to Gottlieb, Orwell attacked his 'adversaries,' the leftist intellectuals, for forgetting the spiritual dimension of the Socialist Movement, which was human brotherhood (1992: 225). Reilly notes that "his investigations into the strange new disease of power worship carried him into regions usually prohibited to the conventional leftist" (1986: 58). Thus, it would be naïve to believe that Orwell was liable to vulnerability simply because he was an armed participant in the Spanish Civil War and not just a journalist, an isolated observer. Physical risk could be described as 'prosaic' in comparison with the complexity of Orwell's ideological 
vulnerability: in Spain, he became "tragically aware of the gulf between wish and fact" (Reilly, 1986: 30) and, perhaps, he was about to give up his humanist belief in man's potential to achieve perfection, accepting that our alienating drive for power is incorrigible. Therefore, his continual exposition to events that went against his ideals, provided his natural pessimism with abundant fuel (Zwerdling, 1974: 81).

When he came to Spain in 1936, Orwell still regarded the Spanish War as a struggle of a firmly united Republic against the fascist rebellion. The 'ugly rumours' about the causes of the loss of Málaga demythologise this ingenuity: "It was the first talk I heard of treachery or divided aims [...] It set up in my mind the first vague doubt about this war in which, hitherto, the rights or wrongs had seemed so beautifully simple" $(45)^{8}$. Orwell's literary response to the breakdown in his former certainty is the creation of an emotive language which becomes a powerful descriptor for his vulnerability: he cannot define what he is experiencing as 'division' or 'conspiracy' because he was a dreamer, fighting in Spain for humanity and justice. Consequently, the word 'nightmare' was the most suitable synonym for referring to corruption and treachery. After the attacks on the buildings belonging to the workers by the republican Assault Guards, the climate in Barcelona is described as "a nightmare atmosphere" (151) and the evening he spent fortifying his POUM building to defend it from the attacks of his 'leftist brothers', as "long and nightmarish" (128).

The historical accounts of Orwell's position in the Spanish Civil War have always highlighted his vulnerability. Woodruff describes him as "a member of what was destined to be the weaker and persecuted side in the conflict between anarchists and communists" (1997: 131) and Gorer refers to his complete ignorance of the Spanish political groupings, which caused him to enrol in the militia of the POUM, "a small dissident Marxist Party, Trotskyist in so far as it was anti-Stalinist and believed in world revolution" (1997: 122). In addition to this, his POUM unit was intrinsically weak. Its men had no boots and wore instead 'rope-soled' sandals, metaphors for their vulnerability (52). The recruits were "mostly boys of sixteen or seventeen from the back streets of Barcelona, full of revolutionary ardour but completely ignorant of the meaning of war" (7). Their shouts of 'Visca POUM!' or 'Fascistas-maricones,' which were meant to be war-like and menacing, "sounded as pathetic as the cries of kittens. It seemed dreadful that the defenders of the Republic should be this mob of ragged children carrying worn-out rifles which they did not know how to use" (18).

After abandoning that mythical Barcelona in which the workers' revolution was still in full swing, Orwell went to the sierras and experienced the ideological vulnerability produced by paralysis. He declared that he had merely existed "as a sort of passive object" at his POUM unit on the Huesca Front (82). Although the POUM militia occupied the positions closest to Huesca, Orwell's days were spent watching the city in the distance as if it were an unattainable dream, "glittering small and clear like a city of doll's houses" (45). Constant rumours of forthcoming battles were deliberately circulated to keep up the

\footnotetext{
${ }^{8}$ Málaga was taken by the fascist rebels in February. The civil authorities, together with many militiamen (namely, Anarchists belonging to the CNT) fled to Almeria. There, some members of the Republican Government tried to persuade the anarchists to surrender their weapons 'in order to avoid problems.' They refused to do so, and there were several important clashes between both sides. This was an anticipation of what was going to happen in Barcelona during the month of May.
} 
spirits of "a weapon-starved army" (71). In fact, "the real preoccupation of both armies was trying to keep warm"(22). On one occasion, Orwell mentions that he knew nothing at the time of the political causes of the stagnation of the Aragón Front. Why was the Aragón Front the mystery front in Spain? It was hardly ever mentioned during the Civil War but, surprisingly, it stretched for about two hundred and fifty miles from the Pyrenees to the Teruel region, including the cities of Huesca and Saragossa whilst guarding Catalonia and Valencia, the most important industrial areas. It is very easy to imagine these abandoned militiamen asking their superiors to look at their maps to see how Huesca was almost entirely surrounded and could be completely taken with a slight effort ${ }^{9}$. Orwell remembered that "months earlier, when Siétamo was taken, the general commanding the Government troops had said gaily: 'Tomorrow we'll have coffee in Huesca',' but this triumphant sentence had turned out to be a standing joke throughout the army (46). In the Homage, Orwell writes about his desire to overcome the distance that separates him from the fascist line, a physical distance which could be considered as a metaphor for an unapproachable but desirable future: "I have felt exactly the same thing when stalking a wild animal; the same agonised desire to get within range, the same dreamlike certainty that it is impossible. And how the distance stretched out!" (66).

For those men isolated in the sierras, real action was the only way of asserting their belief in tomorrow ${ }^{10}$. However, the progressive extermination of those who supported the idea of a militia under workers' control had begun in May 1937. The government of Valencia, increasingly in favour of a capitalist democracy, was not interested in furnishing arms to the most revolutionary section of the troops. They preferred to issue them to the police and the Popular Army forces. A lyrical and desperate interrogation, formulated by Robert Jordan in For Whom the Bell Tolls, denounced that the purest ideals were succumbing to the cancer of power-worship: "Who else kept that first chastity of mind about their work that young doctors, young priests and young soldiers usually started with?" (1999: 255). After abandoning the front, Orwell was hurt by the sight of the Republican troops in Barcelona: "I had not known that the Republic possessed troops like these," he wrote, "it was not only that they were picked men physically, it was their weapons that most astonished me. All of them were armed with brand-new rifles of the type known as "the Russian rifle"" (125). He recalled the Aragón Front, where "the whole militia

\footnotetext{
9 The POUM militia in the Aragón Front had been abandoned. Its 'microscopic' abandonment must be coupled with the 'macroscopic' abandonment of the Republic by the International Forces. According to Cunningham, "early in the summer [of 1937], when the Republic did urgently need help, especially aeroplanes, and when obvious sources of arms like France and even Britain were quickly blocked because of the non-interventionist policies these countries succumbed to, international Stalinism was reluctant to assist a government and country where Anarchism and anti-Stalinism, not to say even Trotskyism, appeared strong and were widely condoned" (1996: 35).

${ }^{10}$ In For Whom the Bell Tolls, Andrés fervently desires to kill fascists: "Tomorrow can be a day of much valid action. Tomorrow can be a day of concrete acts. Tomorrow can be a day which is worth something. That tomorrow should come and that I should be there" (1999: 393). However, Sordo realises that their situation of paralysis will lead to the guerrilleros' extermination: "We exist here by a miracle. By a miracle of laziness and stupidity of the fascists which they will remedy in time." Pilar, one of the most powerful characters in Hemingway's novel, describes the hills north of Guadarrama as an infected sore, the guerrilleros being "the very pus of it" (1999: 163, 329).
} 
chafed against inaction and clamoured constantly to know why [they] were not allowed to attack" (32). When he was about to kill two fascists, he came across a used cartridge: Orwell considered this a bad omen. He knew that his people would fight forever if they were well armed: sentences such as "we had set our hearts on capturing a machine gun" (71) or "it was a great pity about the telescope. The thought of losing that beautiful bit of loot worries me even now" (79), indicate that the lack of weapons was not simply a material problem: it caused emotional and ideological exhaustion.

In May, Orwell went back to Barcelona with an innocent desire for a hot bath and a clean bed (82). He remembered "men's exhausted faces, unshaven, streaked with mud and blackened to the eyes with smoke" (78), their physical vulnerability causing them to become less and less concerned about utopian dreams: "When you are taking part in events like these you are, I suppose, in a small way, making history, and you ought by rights to feel like an historical character. But you never do, because at such times the physical details always outweigh everything else" (120).

For three months, Orwell had been isolated in the sierras among people who could "not too inaccurately be described as revolutionaries" (82). The dirt, the ragged clothes and the feeling of comradeship and equality — so characteristic of the Aragón Frontpervaded the atmosphere on the train all the way to Barcelona. However, when the train rolled into the city, "we stepped into an atmosphere that was scarcely less alien and hostile to us and our kind than if this had been Paris or London" (88). Those men who were returning to Barcelona to kill paralysis and feed their starving minds on its revolutionary example found that those who had previously promoted revolution, were now trying to prevent it. Young men no longer wanted to be part of the militias and, instead, preferred to join a Popular Army which was recruiting at the rate of one officer to ten men (89). A militiaman had to be converted into a regular soldier and, of course, he counted as a deserter if he tried to go home. There was an ongoing and systematic propaganda against the militias, which were described as undisciplined: "'The front' had come to be thought of as a mythical far-off place to which young men disappeared and either did not return or returned after three or four months with vast sums of money in their pockets" (91), but Orwell knew that a militiaman received his back pay when he went on leave.

Barcelona, the so-called revolutionary city, was perhaps the only non-fascist city in the world that had no celebrations on the 1st of May. The paralysis of the revolution could also be felt in this town of a million people which was locked "in a sort of violent inertia, a nightmare of noise without movement" (111). The turning point of the frictions between Anarchists and Communists came also in May with the Government's decision to take over some key industries controlled by the CNT, the Anarcho-Syndicalist trade union: in Barcelona, they seized the Telephone Exchange Building by armed force. The attack on this building fills an entire chapter of Homage to Catalonia. Through an artful literary depiction of this event, Orwell turns it into a fatalist symbol foreshadowing the defeat of the workers' revolution: "Over the Telephone Exchange the Anarchist flag had been hauled down and only the Catalan flag was flying. That meant that the workers were definitely beaten" (123). Orwell left the definition of 'workers' unspecified because he did not want to refer exclusively to the CNT workers who had been attacked, but to the working-class 
movement throughout Spain. This first-person experiencing of treason made him even more vulnerable to disillusionment.

Poets had joined the International Brigades to overcome their alienated existences, to find a meaningful relationship between their art and their society. They felt Spain a lyrical, decisive spot. However, the mythical conception of the Spanish Civil War as 'the war of poets' was being deconstructed in the small space between the Café Moka and the Poliorama cinema on the Ramblas in Barcelona. Orwell sat there, on the roof of the cinema, watching the Assault Guards who were also waiting on the roof of the Café Moka. He was preparing to fire against them in case they attacked the POUM building: "It was one of the most unbearable periods of my whole life. I think few experiences could be more sickening, more disillusioning, or, finally, more nerve-racking than those evil days of street warfare" (111). And, from the roof of the Café, he had heard an Assault Guard declaring: "We don't want to shoot you. We're only workers, the same as you are'" (114). Perhaps, he also remembered what used to happen in the front: Socialists or Anarchists freezing at their posts and shouting the slogan 'Don't fight against your own class' to convert their enemies instead of shooting them (42).

There was a 'visual fascism' in Barcelona which was both pervasive and damaging. It also contributed to crushing Orwell's spirit. If he had been previously shocked by the absence of beggars in the streets, now "outside the delicatessen shops at the top of the Ramblas gangs of barefooted children were always waiting to swarm round anyone who came out and clamour for scraps of food" (93). He saw "a window full of pastries at staggering prices" (95) and, finally, "a cartoon representing the POUM as a figure slipping off a mask marked with the hammer and sickle and revealing a hideous, maniacal face marked with the swastika" (126). These visual elements were very different from "the face of a man who would commit murder and throw away his life for a friend" (1), the image which opened the Homage. And meanwhile, in the 'other' Spain, controlled by the fascist rebels, portraits of a 'deified' Franco and of the Virgin Mary appeared side by side in the churches ${ }^{11}$.

At this point, Orwell implies that he badly needed to go back to his POUM unit on the Huesca Front, where "all or nearly all of the vicious hatreds of the political parties evaporated" (155). In the first pages of the Homage, he had promised not to idealise the POUM militia because he did not want to write a book of propaganda but, in the Aragón Front, he had experienced a living truth. The soldiers had attempted to produce within the militias a temporary working model of the ideal society:

\footnotetext{
${ }^{11}$ González Duro quotes some valuable words extracted from an article published on February 11, 1937, in Seville's journal $A B C$. They deal with 'Franco's canonization': "He visto días pasados en un pueblecito castellano, próximo a la raya de los rojos, cómo en una apoteosis de cruces y banderas, de niños escolares y de todo un vecindario endomingado, avanzaba el alcalde por la nave central de la iglesia, llevando la imagen de Jesús, que al terminar la misa iba a ser entronizada en el ayuntamiento, y escoltado de otros dos concejales, portador uno de una pintura de la Virgen, y el otro, de un retrato del Generalísimo, que seguidamente fue instalado en el Altar Mayor, del lado de la epístola". One of the factors leading to Franco's deification was the increasing political and ideological unity of the Nationalists: "Ya tenemos un solo caudillo y el águila del imperio ostenta una sola cabeza, la de Franco; también él, como el Divino Maestro, nos habla en parábolas. [...] La masonería y las internacionales no son hijas de la patria; quienes las recuerdan son hijos ilegítimos de la patria" (1992: 204, 218).
} 
The thing that attracts ordinary men to Socialism and makes them willing to risk their skins for it, the 'mystique' of Socialism, is the idea of equality; to the vast majority of people Socialism means a classless society, or it means nothing at all. And it was here that those few months in the militia were valuable to me. For the Spanish militias, while they lasted, were a sort of microcosm of a classless society. In that community where no one was on the make, where there was a shortage of everything but no privilege and no boot-licking, one got, perhaps, a crude forecast of what the opening stages of Socialism might be like (84).

However, in renewed fighting in the front, Orwell was struck in the throat by a bullet. Within the microcosm of Homage to Catalonia, his wound cannot only be interpreted as the consequence of being an active participant in the conflict, as the dramatic breakage of paralysis, of the 'noise without movement' he experienced in Barcelona. Orwell's wound is also the lyrical, perceptible symbol of his inner vulnerability. The blood poured out of his mouth while he heard the Spanish soldiers behind him say that the bullet had gone clean through his neck. He felt the alcohol "splash onto the wound as a pleasant coolness" (138). He miraculously survived but when, after his recovery, he returned to Barcelona, the POUM - now considered to be Franco's fifth column — had been outlawed and its members "accused of being in Fascist pay" (160). Orwell's physical wounds had been healed, but his 'ideological pain' was increased. The banning of the POUM meant the betrayal of all the more utopian aims of the Spanish Left. In one of his inner monologues, Robert Jordan literaturises the possible thoughts of a George Orwell possessed by despair:

Muck this whole treacherous muck-faced mucking country and every mucking Spaniard in it on either side and to hell forever. Muck them to hell together, Largo, Prieto, Asensio, Miaja, Rojo, all of them. Muck every one of them to death to hell. Muck the whole treacheryridden country. Muck their egotism and their selfishness and their selfishness and their egotism and their conceit and their treachery. [...] Muck them before we die for them. Muck them after we die for them. [...] God pity the Spanish people. Any leader they have will muck them. [...] Muck everybody but the people and then be damned careful what they turn into when they have power (1999: 396).

As a member of the outlawed POUM, Orwell had to hide from the 'Stalinist' police and, consequently, he was forced to lead a dual existence, to go back into the middle-class identity from which the Spanish revolution had enabled him to break free: "It was an insane existence that we were leading. By night, we were criminals, but by day we were prosperous English visitors. The safest thing was to look as bourgeois as possible" (181). The unjust imprisonment of George Kopp, the Belgian commander, contained the essence of everything that Orwell abhorred. Kopp had sacrificed everything to come to Spain and fight against Fascism: he had joined a foreign army while he was in the Belgian Army Reserve and, therefore, had left his country without permission. He had even helped to manufacture munitions illegally for the Spanish Government and now, as many volunteers were, he was alone, betrayed and isolated. Orwell considered Kopp as a metaphor for decency. Atkins has defined 'decency' as something based on respect for the other person, a respect which derives from love, from the quieter passion, or conviction, that all men are brothers (1965: 6). As Gottlieb has pointed out, Orwell's courage as a humanist lies in his 
insistence on facing the vacuum created by hypocrisy and power-worship, relying on human decency (1992: 237). He wrote Homage to Catalonia to defend "people who represent courage, humaneness and decency against those who would slander and misrepresent them for political or personal advantage" (Alldritt, 1969: 86). After the references to Kopp's imprisonment, through a small symbolic action, Orwell rewrites vulnerability into resistance: although the revolutionary slogans Visca POUM and Visca la Revolución were being systematically removed from every wall, Orwell took to writing them on the passages of smart restaurants in Barcelona (181). He had discovered, after all, that loyalty and humanity were not abstractions. The spirit of resistance which pervades the Homage was contained in Orwell's 'graffiti'.

The people in Catalonia had attained freedom, perhaps for the first time, and had rediscovered each other anew as human beings. The references to the fact that the Spanish soldiers gave Orwell their week's ration of tobacco, when it could not be bought anywhere in the town, also acquire a symbolic dimension: as Reilly has pointed out, Orwell believed that dehumanised intellectuals should return to the traditional ethics of common people, not to give, but to receive, to learn from their authenticity (1986: 53). While he was in Monzón Hospital, recovering from his wounds, he remembered that at the front, nobody -not even PSUC adherents - showed him hostility because he was a member of the POUM (155) and, although Kopp was "part of a dirty system," he had remained "enough of a human being to know a decent action when he saw one" (180). The months he spent at the front line were less futile than he had at first thought: "They formed a kind of interregnum in my life, quite different from anything that had gone before and perhaps from anything that is to come, and they taught me things that I could not have learned in any other way" $(82)^{12}$. There was a true revolution in Spain which, although temporary, "lasted long enough to have its effect upon anyone who experienced it" (83).

In Orwell's previous novels, as Zwerdling has noted, the major characters were appalled by the conditions of their lives as they are determined by institutions. Their attempts to escape were illusory, since the forces of society were stronger than their rebelliousness (1974: 64). However, in the Homage, the writer offers a challenging vision of vulnerability. As I have previously mentioned, vulnerability appears as the consequence of being ideologically alive within an alienating environment: Orwell knew that the street-fighting in Barcelona was the visible face of an inner conspiracy against the workers who were trying to defend their previous revolutionary conquests. However, he rewrote his vulnerability into ideological resistance. The humanistic value of the Homage resides in Orwell's vindication of the sanctity of his revolutionary ideals: the awareness of our vul-

\footnotetext{
12 In 1937 John Cookson, an American volunteer, wrote the following letter from Spain: "The most revolutionary thing one can do now is to fight against fascism. The truth of this I am now more certain than ever before. Hence, since I have tried to follow my life in accordance with dialectical materialism it was the only action I could take. [...] But most significant is the revolution in my mind. I shall never think the old way. Now the works of Marx and Lenin are becoming clear in the light of contemporary experiences. One realises on the one hand how little he knows, and on the other hand the methods for changing the world become more comprehensible" (qtd. in Nelson and Hendricks, 1996: 35). This idea of having acquired a new wisdom, also appears in For Whom the Bell Tolls, namely in Robert Jordan's inner reflections: "Educated, he thought. I have the very smallest beginnings of an education. The very small beginnings. If I die on this day it is a waste because I know a few things now" (1999: 408).
} 
nerable condition must not lead to the destruction of our inner beliefs. In Spain, he discovered the valuable things that were hidden under physical, emotional and ideological discomfort. He took strength from the fact that he had seen the future and it had worked. In the Aragón front where he was stationed, he could feel that brotherhood was not a utopia: "However much one cursed at the time, one realised that one had been in contact with something strange and valuable. One had been in a community where hope was more normal than apathy or cynicism, where the word 'comrade' stood for comradeship and not, as in most countries, for humbug (83).

It is obvious that the novel presents some specific political conclusions: Orwell's experiences in Spain, for instance, made his socialism a living faith. As Zwerdling has pointed out, he discovered that Socialism can be stripped of its illusions and still survive (1974: 110). He came to consider socialism as a miraculous fusion of elements which his vulnerability had previously rejected as irreconcilable: power and decency, intelligence and altruism, expertise and humility (Reilly, 1986: 40). Yet, revisiting a text from the past is not only a question of analysing its historical significance within a specific context. It is also a question of assigning new meanings to its past cosmovision. As Spargo has pointed out, we can always find political, ethical and intellectual motivations for reading the past (2000: 2). These motivations give rise to the 'present-ification' of past texts (Hutcheon, 1988: 20). In this sense, Orwell's fight for the Spanish Republic can be also interpreted as a fight against the timeless problem of alienation. Catalonia, the Spanish Civil War, and the people participating in it acquire, thanks to the Homage, an abstract dimension: they are mere narrative vehicles to illustrate that it is possible to overcome alienation and attain freedom. The good Republicans had not only fought against Franco, but also against a plague of pandemic magnitude, "the strange vulnerability of twentieth-century man to the temptation of power-worship" (Reilly, 1986: 40). From my point of view, Homage to Catalonia certainly encourages its revisiting. Its significance can be easily updated because Orwell did not write an 'aseptic' piece of polemical journalism: he contaminated his novel with very human concerns which go beyond the temporal limits imposed by the contextualisation of the novel in the Spanish Civil War. Orwell's Homage also makes literature appear as a 'combative' art, powerful enough to change or modify real life structures: through the literary depiction of his nonconformity, Orwell highlighted the necessity of being ideologically alive, as pertinent an issue today as it was during the time of his own personal homage.

\section{REFERENCES}

AlLDRITT, K. 1969. The Making of George Orwell: An Essay in Literary History. London: Edward Arnold.

Atкins, J. 1965. George Orwell: A Literary and Biographical Study. New York: Frederick Ungar Publishing.

Cunnigham, V., ed. 1996: The Penguin Book of Spanish Civil War Verse. Harmondsworth: Penguin. 
Dunn, D. 1988. 'Importantly Live:' Lyricism in Contemporary Poetry. Dundee: Faber \& Faber.

FAUlKner, P. 1975. Humanism in the English Novel. London: Elek/Pemberton.

FreEdMAn, C. 1988. George Orwell: A Study in Ideology and Literary Form. New York: Garland Publishers.

GonZÁLEZ Duro, E. 1992. Franco: una biografía psicológica. Madrid: Ediciones Temas de Hoy.

Gorer, G. 1997. Rev. of Homage to Catalonia, by George Orwell. George Orwell: The Critical Heritage. Ed. J. Meyer. London: Routledge, 121-123. (Reprinted from Time and Tide 30 April 1938: 599-600).

Gottlieb, E. 1992. The Orwell Conundrum: A Cry of Despair or Faith in the Spirit of Man? Ottawa: Carleton University Press.

Hemingway, E. 1999 (1941). For Whom the Bell Tolls. London: Vintage.

Hutcheon, L. 1988. A Poetics of Postmodernism: History, Theory and Fiction. New York: Routledge.

Mairet, P. 1997. Rev. of Homage to Catalonia, by George Orwell. George Orwell: The Critical Heritage. Ed. J. MeYER. London: Routledge, 127-130. (Reprinted from New English Weekly 26 May 1938: 129-30).

Nelson, C. \& J. HendRICKs, eds. 1996. Madrid 1937. Letters of the Abraham Lincoln Brigade from the Spanish Civil War. New York: Routledge.

Orwell, G. 2000 (1938). Homage to Catalonia. London: Penguin.

Pierce, D. \& P. DE Voogd, eds. 1996. Laurence Sterne in Modernism and Postmodernism. Amsterdam: Rodopi.

ReILly, P. 1986. George Orwell: The Age's Adversary. Houndmills: Macmillan.

Spargo, T., ed. 2000. Reading the Past. Houndmills: Palgrave.

Spender, S. 1997. Rev. of Homage to Catalonia, by George Orwell. George Orwell: The Critical Heritage. Ed. J. MeYER. London: Routledge, 134-137. (Reprinted from World Review June 1950: 51-4).

Thomas, H. 1997. Rev. of Homage to Catalonia, by George Orwell. George Orwell: The Critical Heritage. Ed. J. MEYER. London: Routledge, 150-152. (Reprinted from New Statesman 20 April 1962: 568).

1964. The Spanish Civil War. London: Eyre \& Spottiswoode.

Woodruff, D. 1997. Rev. of Homage to Catalonia, by George Orwell. George Orwell: The Critical Heritage. Ed. J. MEYER. London: Routledge, 131-134. (Reprinted from Tablet 19 July 1938: 48).

ZimMERMAn, S. M. 1999. Romanticism, Lyricism and History. New York: State University of New York Press.

Zwerdling, A. 1974: Orwell and The Left. New Haven: Yale University Press. 